\title{
TLC and GC-MS Analyses of Essential Oil Isolated from Macedonian Foeniculi fructus
}

\author{
Menče Najdoska ${ }^{1}$, Jane Bogdanov ${ }^{1 *}$, Zoran Zdravkovski $^{1}$ \\ ${ }^{1}$ Institute of Chemistry, Faculty of Natural Sciences and Mathematics, "Sts. Cyril and Methodius University" Arhimedova \\ 5, MK-1001, Skopje, Republic of Macedonia
}

Received: February 2011; Accepted: May 2011

\begin{abstract}
Summary
The essential oil of Foeniculi fructus, the ripe fruit from the plant Foeniculum vulgare Mill. ssp. vulgare var. dulce Batt. and Trab. (sweet fennel, македонски анасон) was isolated and the main components were identified and quantified using thin-layer chromatography (TLC) and gas chromatography and mass spectrometry (GC-MS). The Aetherloeum Foeniculi had pale yellow color and characteristic pleasant odor and was obtained in 3.2\% yield (by weight from the plant fruits). The main components of the oil were: trans-anethole, 1 , (70\%), $p$-anisaldehyde, 2, (19\%) estragole, 3, (6\%) and anisacetone, 4, (2\%). The identity of the components was determined by matching the mass spectra to the library spectra. The identity of the main component, trans-anethole, was confirmed directly by isolation using column chromatography and indirectly by potassium permanganate oxidation of the essential oil. The oxidation product from this reaction, $p$ methoxybenzoic acid, 16, was isolated and characterized. The potential products of autooxidation of trans-anethole (epoxy anethole, anethole glycol and 16) were not detected in the freshly obtained essential oils.
\end{abstract}

Key words: Foeniculum vulgare Mill. ssp.vulgare var. dulce, sweet -fennel fruit essential oil, chemical composition, GC-MS, transanethole.

\section{Introduction}

The charastersistic aromas of the plants are due to volatile or essential oils, which have been used since the antiquities as a source of fragrances and flavorings (Lawless, 1995). These oils occur in all the living parts of the plant, but they are usually concentrated in twigs, flowers and seeds. Essential oils are generally complex mixtures of various classes of organic compounds such as hydrocarbons, alcohols, and carbonyl compounds.

Essential oil from Foeniculi fructus (sweet fennel, Roman fennel, Macedonian fennel, mac. сладок анасон) is obtained from the ripe and dry fruits of the plant Foeniculum vulgare Mill. ssp. vulgare var. dulce Batt. and Trab., (Dervendji, 1986). It is usually cultivated in the countries of Southern Europe (France, Italy and Macedonia). The most common way to obtain essential oil of sweet fennel

\footnotetext{
j_b_bogdanov@yahoo.com
}

fruits is by steam distillation of the crushed (milled) fruits. The fruits contain between $2-6 \%$ by weight of the essential oil (Dervendji, 1986; Guenther, 1952; Kulevanova, 2004). The essential oil, Aetheroleum Foeniculi, is clear, mobile, colorless or pale yellow liquid with pleasant aromatic smell and delicate sweet flavor (Dervendji, 1986; Guenther, 1952; Kulevanova, 2004). It has a widespread use in food, beverage, fragrance and pharmaceutical industry and also finds use in the folk medicine. The fennels fruits has been used as an antispasmodic, carminative, diuretic, expectorant, laxative, stimulant and stomachic and have a long history of use in both Western and Eastern cultures. As far as Macedonia is concerned, the most famous use of sweet fennel fruits is in the preparation of the alcoholic drinks "mastika" and "anasonka" (Dervendji, 1986; Kulevanova, 2004).

The chemical composition of the essential oil derived from sweet fennel fruits varies widely depending on geographic location, climate and cultivation. The oils of sweet fennel seeds, obtained by steam distillation, most common- 

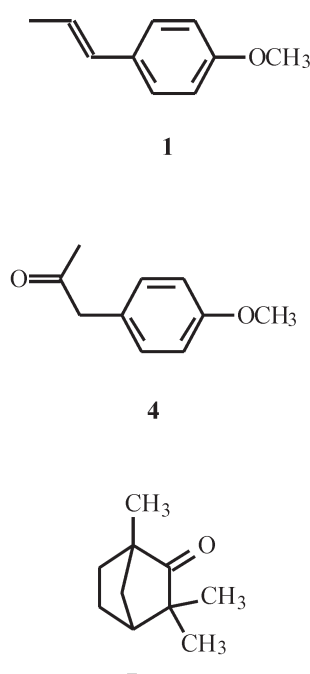<smiles>CC1CC2(C)CCC1C(C)(C)O2</smiles>

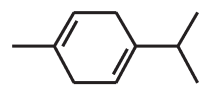

13

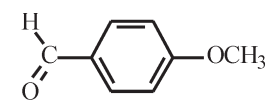

2
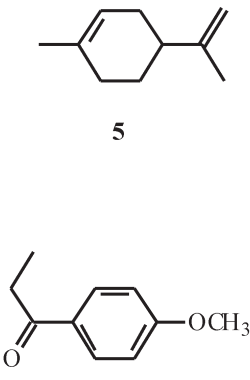

8

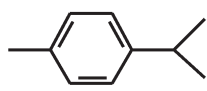

11

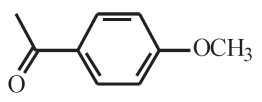

14
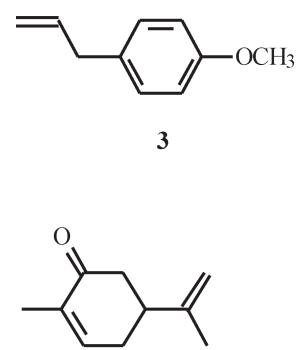

6
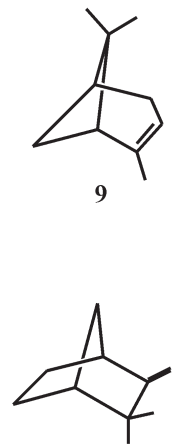

12

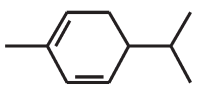

15

Fig. 1. Chemical constituents of fennel essential oil: (1) trans-anethole, (2) $p$-anisaldehyde, (3) estragole, (4) aniseacetone, (5) limonene, (6) carvone, (7) d-fenchone, (8) 4-methoxypropiophenone, (9) $\alpha$-pinene, (10) eucaliptol, (11) $p$-cymene, (12) camphene, (13) $\gamma$-terpinene, (14) $p$-methoxyacetophenone, (15) $\alpha$-phelandrene.

ly contain: trans-anethole, $\mathbf{1}, p$-anisaldehyde $\mathbf{2}$, estragole, 3, anisacetone, 4, limonene, 5, carvone, 6, d-fenchone, 7, 4-methoxypropiophenone, $\mathbf{8}, \alpha$-pinene 9 , eucaliptol 10, $p$ cymene 11, camphene, 12, $\gamma$-terpinene, 13, $p$-methoxyacetophenone, 14, and $\alpha$-phelandrene 15 (Azeez, 2008; Krishna 2004). It can be seen from scheme 1 that the essential oil is dominated by phenylpropanoids and monoterpenes. It has been established that the main constituent of the sweet fennel is trans-anethole (60-89\%). It has been established that the higher the content of trans-anethole and lower the content of fenchone results in sweet fennel oil of higher quality. For comparison purposes, bitter fennel oil is thought to contain more fenchone (12-25\%) and less transanethole $(55-75 \%)$ than sweet fennel oil (Ph. Eur. $7^{\text {th }}$ ed.). Sweet fennel oil is of a superior quality with a more pleasing aroma and flavor.

Even though, the chemical composition of the sweet fennel essential oil can vary depending on the geographic region and climate, there are some substantial discrepancies in the literature over the abundance of the other compounds especially fenchone, estragole, limonene and anisaldehyde. Karlsen and co-workers (1969) have report- ed composition of sweet fennel oil with $52.0 \%$ anethole, $2.5 \%$ estragole, $28.9 \%$ limonene and $2.7 \%$ fenchone. Akgül and Bayrak (1988) have done studies on fennel grown in Turkey and found on average $75-85 \%$ trans-anethole, $4 \%$ estragole and $2 \%$ fenchone.

The main objective of this work was to isolate the essential oil from Macedonian sweet fennel and to identify and quantify its main components using thin-layer chromatography (TLC) and gas chromatography and mass spectrometry (GC-MS). Another issue that is of significance, in terms of quality of the fennel and also of the Aetheroleum Foeniculi, is the auto-oxidation of trans-anethole. There are several proposed intermediates in this process, (epoxyanethole and anethole glycol) and the final product of autooxidation is considered to be $p$-methoxybenzoic acid (Kitajima et al., 1999). We were curious to see if we could observe these compounds in the essential oil. Additionally, as minor objective of this study, was to investigate the reactivity of trans-anethole in oxidation reactions via chemical means, in connection to the mechanism of its autooxidation. 


\section{Material and methods}

\section{General part}

Melting points were determined with Mel-Temp apparatus and were uncorrected. Infrared spectra were measured on a Perkin-Elmer System 2000 FT IR, by the method of $\mathrm{KBr}$ pellets. All the reagents and solvents were obtained from commercial sources and were used without further purification. Thin-layer chromatography was carried out using Merck pre-coated plates $\left(60, \mathrm{GF}_{254}, 250 \mu \mathrm{m}\right)$ and examined under UV light or with sulfuric acid reagent. Preparative flash chromatography (Still et. al. 1978) was performed using Merck silica gel 60 (230-400 mesh). The fruit of sweet fennel (македонски анасон, Foeniculi fructus Series: 010207), methylene chloride, sodium sulfate, potassium permanganate, sodium hydroxide, sodium bisulfite, concentrated sulfuric acid and 37\% hydrochloric acid were obtained from Alkaloid AD Skopje. trans-Anethole, fenchone, estragol and anisaldehyde were obtained from Sigma-Aldrich and tetrabutylammonium chloride was obtained from Fluka. Toluene, hexane, ethyl acetate and 4-methoxybenzoic acid were obtained from Merck.

\section{Gas chromatography}

GC/MS analysis of Aetherloeum Foeniculi was carried out on Agilent Technologies 6890N GC Network system, equipped with 7683B Series injector autosampler and 5975B Inert XL,EI/CI MSD mass spectral detector. GC column: HP-5MS, 30 m x 0.250 mm, 0.25 microns. Temperature programme: starting temperature $70{ }^{\circ} \mathrm{C}(2 \mathrm{~min})$, $15^{\circ} \mathrm{C} / \mathrm{min}$ to $250^{\circ} \mathrm{C}$ (4 min). The MS detection was carried out in the electron impact mode with an ionization energy of $70 \mathrm{eV}$ and with a scan range of 45-400 amu. The carrier gas was helium with a flow rate of $1 \mathrm{~mL} / \mathrm{min}$. The temperature of injector was set at $250{ }^{\circ} \mathrm{C}$, transfer line temperature was set at $240{ }^{\circ} \mathrm{C}$ and the ion source at $250{ }^{\circ} \mathrm{C}$. The chromatograms were analyzed using the MSD Chemstation software package and the mass spectra were compared and matched with both NIST 05 and the Wiley $8^{\text {th }}$ edition registry mass spectral databases (W8/N05). The Aetherloeum Foeniculi was diluted with methylene chloride to give a $0.5 \mathrm{mg} / \mathrm{mL}$ solution of which $1 \mu \mathrm{L}$ was injected in split mode (1:40). For the quantification purposes percent area was reported without correction indices. Portion of one of the isolated essential oils obtained was injected three times and an average of the percent area for the components were calculated.

\section{Isolation of essential oil from Foeniculi fructus}

Freshly ground Foeniculi fructus (10 g) was placed in a $250-\mathrm{mL}$ round-bottom flask, followed by $100 \mathrm{~mL}$ of water and a boiling stone and apparatus for steam distillation was assembled. The mixture was heated until steady distillation began. Water was added occasionally to maintain the original level and the distillate was collected $(\sim 100 \mathrm{~mL})$ until no droplets could be seen. The distillate was extracted with methylene chloride $(3 \times 10 \mathrm{~mL})$ and the combined organic layers were dried over sodium sulfate. Gentle evaporation of the solvents resulted in pale yellow oil with characteristic and pleasant odor. The distillation was repeated three more times giving an average yield of essential oil for the four distillations of $3.2 \%$ by weight from the plant fruits. One sample of the essential oil was used for triplicate TLC and GC-MS analyses. Two of the isolated essential oils were subjected to oxidation and one of the isolated essential oils was used for preparative flash chromatography.

\section{TLC analysis of Aetherloeum Foeniculi}

Portion of one isolated essential oils $(0.1 \mathrm{~mL})$ was dissolved in methylene chloride $(5 \mathrm{~mL})$ and also the available standards were dissolved in methylene chloride and were subjected to the following analyses. The samples were applied onto a Merck silica gel pre-coated plate $\left(60, \mathrm{GF}_{254}\right.$, $250 \mu \mathrm{m}$ ) and developed with 93:7 toluene/ethyl acetate, as a mobile phase over a path of $10 \mathrm{~cm}$. The spots were initially detected with UV light (254 nm) and then with sulfuric acid $\left(140{ }^{\circ} \mathrm{C}\right.$ for 5 minutes). The second solvent system was 5:1 hexane/methylene chloride and the spots were visualized first with UV light (254 nm) and then with sulfuric acid $\left(140{ }^{\circ} \mathrm{C}\right.$ for 5 minutes).

\section{Isolation of trans-anethole from Aetheroleum Foeniculi via Flash chromatography}

The essential oil $(0.30 \mathrm{~g})$ was dissolved in minimal amount of 3:1 mixture of hexane/methylene chloride and applied onto a pre-equilibrated silica gel column. The mixture was eluted with $5: 1(\mathrm{v} / \mathrm{v})$ hexane/methylene chloride. The trans-anethole containing fractions were detected via TLC and combined. Removal of solvent and brief drying in vacuo resulted in $0.162 \mathrm{~g}$ of trans-anethole, 1. mp 19$20{ }^{\circ} \mathrm{C}$ (lit.(Lide, 2003) $20-21^{\circ} \mathrm{C}$ ), $\mathrm{R}_{\mathrm{f}}\left(5: 1\right.$ hexane $/ \mathrm{CH}_{2} \mathrm{Cl}_{2}$ ) $=0.38, \mathrm{R}_{\mathrm{t}}(\mathrm{GC}-\mathrm{MS})=8.03 \mathrm{~min}$, IR (liquid film): 3024, 3003, 2958, 2934, 2914, 2836, 1609, 1577, 1511, 1466, $1455,1441,1306,1284,1247,1175,1036,955,944,840$, 788, $756 \mathrm{~cm}^{-1}$. EI-MS ( $\mathrm{m} / z$, relative intensity): $148\left(\mathrm{M}^{+}\right.$, $100 \%), 147\left(\mathrm{M}^{+}-1,54 \%\right), 133\left(\mathrm{M}^{+}-\mathrm{CH}_{3}, 25 \%\right), 121(18 \%)$, $117\left(\mathrm{M}^{+}-\mathrm{OCH}_{3}, 33 \%\right), 105$ (26\%), 103 (19\%), 91 (17\%), $77(27 \%)$.

\section{Oxidation of Aetheroleum Foeniculi}

The oxidation was performed with a modification of the original procedure described by Garin (1980). To a mixture of potassium permanganate $(0.5 \mathrm{~g})$ in distilled water $(10 \mathrm{~mL})$, seven drops of $10 \%$ solution of tetrabutylammonium chloride and two drops of $10 \%$ sodium hydroxide were added. When the potassium permanganate com- 
pletely dissolved, $0.30 \mathrm{~g}$ of Aetheroleum Foeniculi were added and the mixture was stirred for 5 minutes at ambient temperature and then for 30 minutes on a boiling water bath. As the reaction proceeds, brown precipitate forms and deposits on the walls of the reaction vessel. The reaction mixture was cooled to room temperature and acidified with $6 \mathrm{M}$ hydrochloric acid to a $\mathrm{pH}$ of 2 . Sodium bisulfite was added with stirring until the reaction mixture become clear (no pink color or brown precipitate) and white precipitate remained. The $\mathrm{pH}$ was adjusted to 2 with $6 \mathrm{M}$ hydrochloric acid, the mixture was cooled in an ice bath for 1 hour. The white precipitate was collected via vacuum filtration, washed with ice-cold distilled water and dried. The oxidation was repeated one more time under the same conditions. The average yield of 4-methoxybenzoic acid, 16, from the two reactions was $0.062 \mathrm{~g} . \mathrm{mp} 183-186^{\circ} \mathrm{C}$ (lit. (O'Neal, 2001) mp 184-187 ${ }^{\circ} \mathrm{C}$ ). IR (KBr): 3300-2500 (br. OH stretch), 3029 (aromatic C-H stretch), 2956 (aliphatic C-H stretch), 2941 (aliphatic C-H stretch), 2845, 2729, 2675, 2664, 1688 (C=O stretch), 1608, 1580, 1518, 1429, $1307,1301,1267,1181,1172,1028,929,854,845,825$, $774 \mathrm{~cm}^{-1}$. The isolated trans-anethole (described above) was subjected to the same oxidation conditions and 4-methoxybenzoic acid was obtained.

\section{Results and discussion}

The essential oil of Foeniculi fructus was obtained by steam distillation ( $3.2 \%$ by weight from plant fruit). This value is in agreement with the literature (Dervendji, 1986; Guenther, 1952; Kulevanova, 2004), which gives values ranging from $2 \%$ to $6 \%$ (by weight). The distillation and subsequent extraction are rather simple and can be scaled up without any problems. The most effective and convenient method for rapid qualitative analysis is thin layer chromatography (TLC). We have employed this method for preliminary analysis of the essential oil. The analysis employing silica gel plates, 93:7 toluene/ethyl acetate as mobile phase and UV light visualization resulted in quenching zone in the top of the plate coresponding to trans-anethole $\left(\mathrm{R}_{\mathrm{f}}=0.94\right)$ and a quenching zone in the middle of the plate corresponding to anisaldehyde $\left(\mathrm{R}_{\mathrm{f}}=0.42\right)$. Then the plate was sprayed with sulfuric a trans-anethole and anisaldehyde at once gave red-violet color. A very faint yellow spot for fenchone $\left(\mathrm{R}_{\mathrm{f}} \sim 0.5\right)$ appears when the plate was heated to $140{ }^{\circ} \mathrm{C}$ for 5 minutes. There is a faint reddish-browspot near the solvent front (terpene hydrocarbons). There are several spots in the bottom half of the plate probably corresponding to the more polar components at the origin.

This analysis was not satisfactory for estragol because it had the same $\mathrm{R}_{\mathrm{f}}$ value as the isomeric trans-anethole. It was discovered that the best separation for non-polar components was achieved using 5:1 hexane/methylene chloride as the mobile phase. With this mobile phase transanethole $\left(\mathrm{R}_{\mathrm{f}}=0.38\right)$ can be separated from estragole $\left(\mathrm{R}_{\mathrm{f}}=\right.$ $0.44)$. When the TLC plate was treated with sulfuric acid was heated to $140{ }^{\circ} \mathrm{C}$ for 5 minutes faint reddish-brown zone appeared at $\mathrm{R}_{\mathrm{f}} \sim 0.85$ (terpene hydrocarbons). The separation was satisfactory to the point of employing the mobile phase for preparative separation using flash chromatography. Indeed, trans-anethole was isolated in 54\% yield based on the starting essential oil and characterized.

The method of choice for qualitative and quantitative analysis of complex organic volatile organic mixtures is gas chromatography coupled with mass spectrometry (Adams, 1995). The isolated essential oil was dissolved in methylene chloride and subjected to the GC/MS analysis. The main components of the oil as determined by GC-MS were: trans-anethole, 1, (70\%), $p$-anisaldehyde, 2, (19\%) estragole, $3,(6 \%)$ and anisacetone, $4,(2 \%)$. Minor constituents that were found were limonene, $5,(0.6 \%)$, carvone, 6 , $(0.5 \%)$, fenchone, $7,(0.5 \%)$ and 4-methoxypropiophenone, $8,(0.5 \%)$. The components present in less than $0.4 \%$ were not taken into consideration. The identity of the products was determined by comparison of retention times with available standards and by matching of the obtained mass spectra to the spectra in both Wiley $8^{\text {th }}$ ed. and NIST 2005 libraries (W8/N05). The electron impact mass spectra of the main components (1-4) are given in figures 3 and 4 .

The identity of the main components matched with the data from the literature (Azeez, 2008; Krishna 2004). Based on the reviews of Lawrence (1980) and Maarse $(1989,1991)$ on the quantitative analyses of fennel oils, it can be concluded that the determined content of transanethole $(70 \%)$ in Macedonian sweet fennel oil was within the described range (60-89\%). Also the identity of the other main components is in the agreement with the literature. Our analysis revealed that based on the chemical composition the essential oil from fennel seed showed most similarity to the one reported by Akgül and Bayrak (1988) (75-85\% trans-anethole, $4 \%$ estragole, $2 \%$ fenchone and

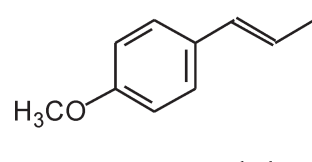

trans-anethole

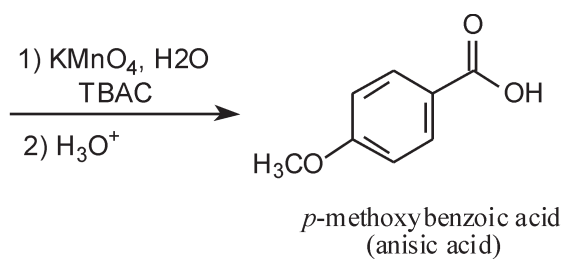

16

Scheme 1. Oxidation of trans-anethole 


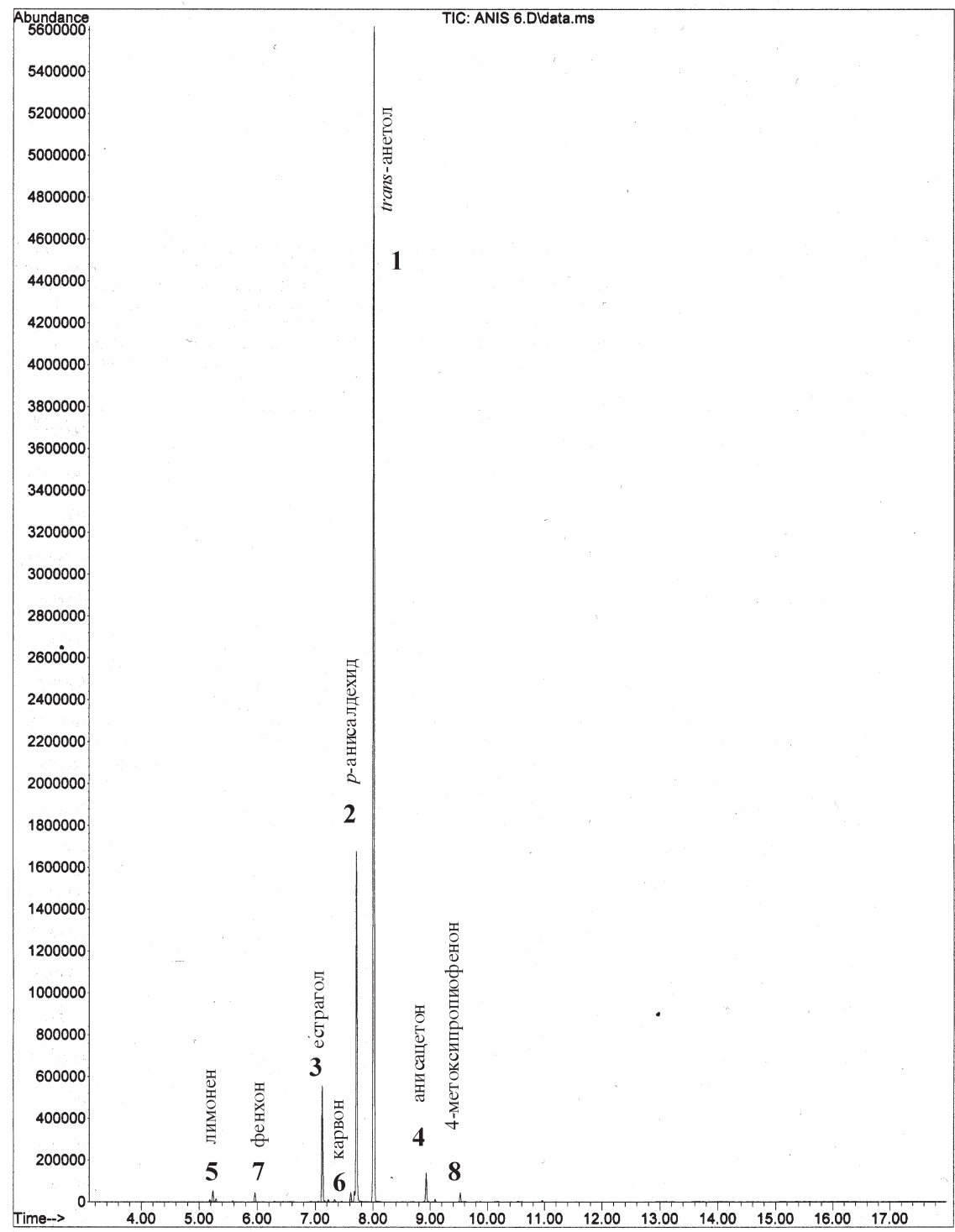

Fig. 2. Gas chromatogram from the analysis of Aetheroleum Foeniculi showing all the major components

Table 1. Key data for the major constituents of the Aetheroleum Foeniculi

\begin{tabular}{|c|c|c|c|c|c|c|}
\hline \multicolumn{2}{|l|}{ Trivial name* } & $\begin{array}{l}\text { CAS reg. } \\
\text { Number }\end{array}$ & $\begin{array}{l}\text { Molecular } \\
\text { formula }\end{array}$ & $\begin{array}{c}\text { Molecular } \\
\text { weight }\end{array}$ & $\begin{array}{c}\mathrm{R}_{\mathrm{t}} \\
(\mathrm{min})\end{array}$ & $\%$ \\
\hline trans-anethole & (1) & [4180-23-8] & $\mathrm{C}_{10} \mathrm{H}_{12} \mathrm{O}$ & 148.20 & 8.02 & 69.8 \\
\hline$p$-anisaldehyde & (2) & {$[123-11-5]$} & $\mathrm{C}_{8} \mathrm{H}_{8} \mathrm{O}_{2}$ & 136.15 & 7.72 & 18.9 \\
\hline estragole & (3) & [140-67-0] & $\mathrm{C}_{10} \mathrm{H}_{12} \mathrm{O}$ & 148.20 & 7.13 & 5.9 \\
\hline anisacetone & $(4)$ & [122-84-9] & $\mathrm{C}_{10} \mathrm{H}_{12} \mathrm{O}_{2}$ & 164.20 & 8.93 & 1.7 \\
\hline limonene & (5) & {$[138-86-3]$} & $\mathrm{C}_{10} \mathrm{H}_{16}$ & 136.24 & 5.24 & 0.6 \\
\hline carvone & $(6)$ & {$[99-49-0]$} & $\mathrm{C}_{10} \mathrm{H}_{14} \mathrm{O}$ & 150.22 & 7.62 & 0.5 \\
\hline fenchone & (7) & {$[1195-79-5]$} & $\mathrm{C}_{10} \mathrm{H}_{16} \mathrm{O}$ & 152.24 & 5.96 & 0.5 \\
\hline 4-methoxypropiophenone & $(8)$ & [121-97-1] & $\mathrm{C}_{10} \mathrm{H}_{12} \mathrm{O}_{2}$ & 164.20 & 9.53 & 0.5 \\
\hline
\end{tabular}

*IUPAC names of the major constituents are: (1) 1-methoxy-4-[(E)-prop-1-enyl]benzene, (2) 4-methoxybenzaldehyde, (3) 1-methoxy-4-(prop-2-enyl) benzene, (4) 1-(4-methoxyphenyl)propan-2-one, (5) 4-isopropenyl-1-methyl-cyclohexene, (6) 5-isopropenyl-2-methyl-cyclohex-2-en-1-one, (7) 1,3,3trimethylbicyclo[2.2.1]heptan-2-one (8) 1-(4-methoxyphenyl)propan-1-one 

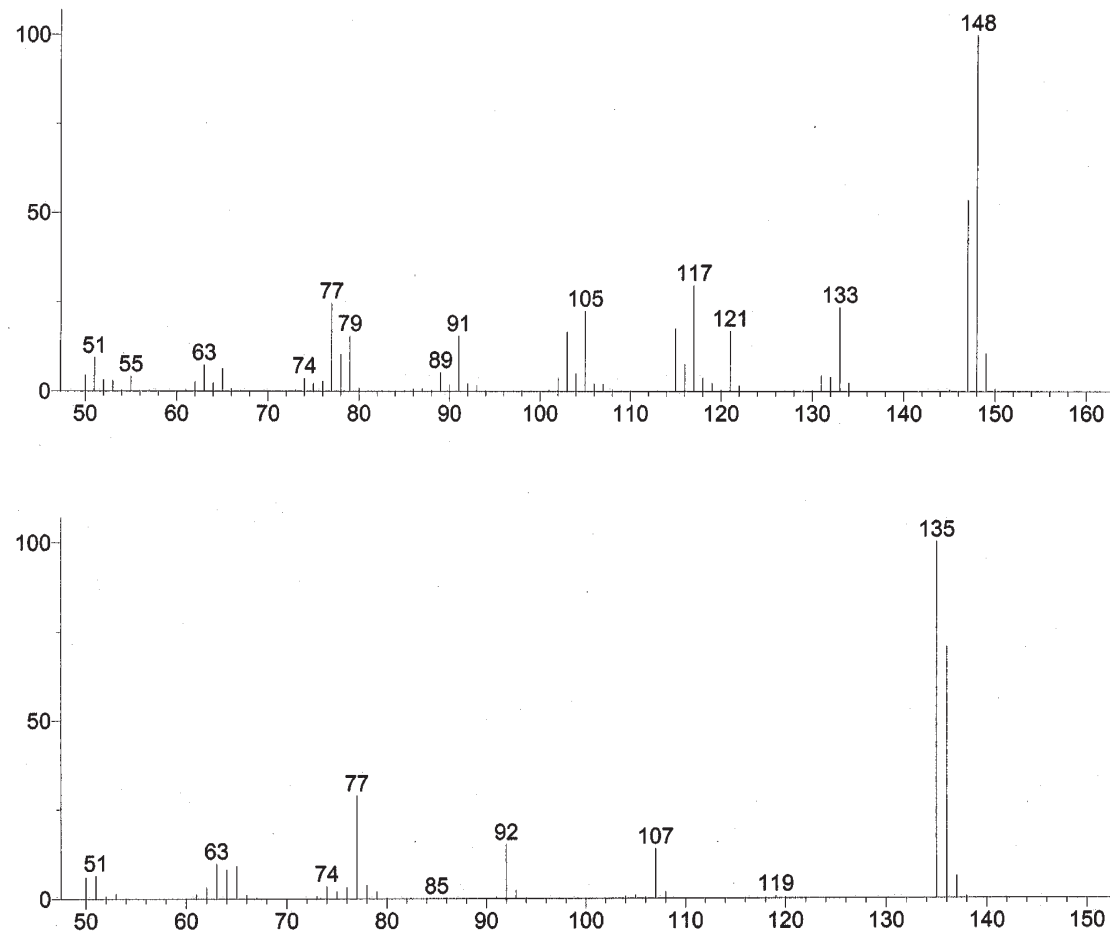

Fig. 3. Electron impact mass spectra of trans-anethole, 1, (top) and p-anisaldehyde, 2, (bottom).
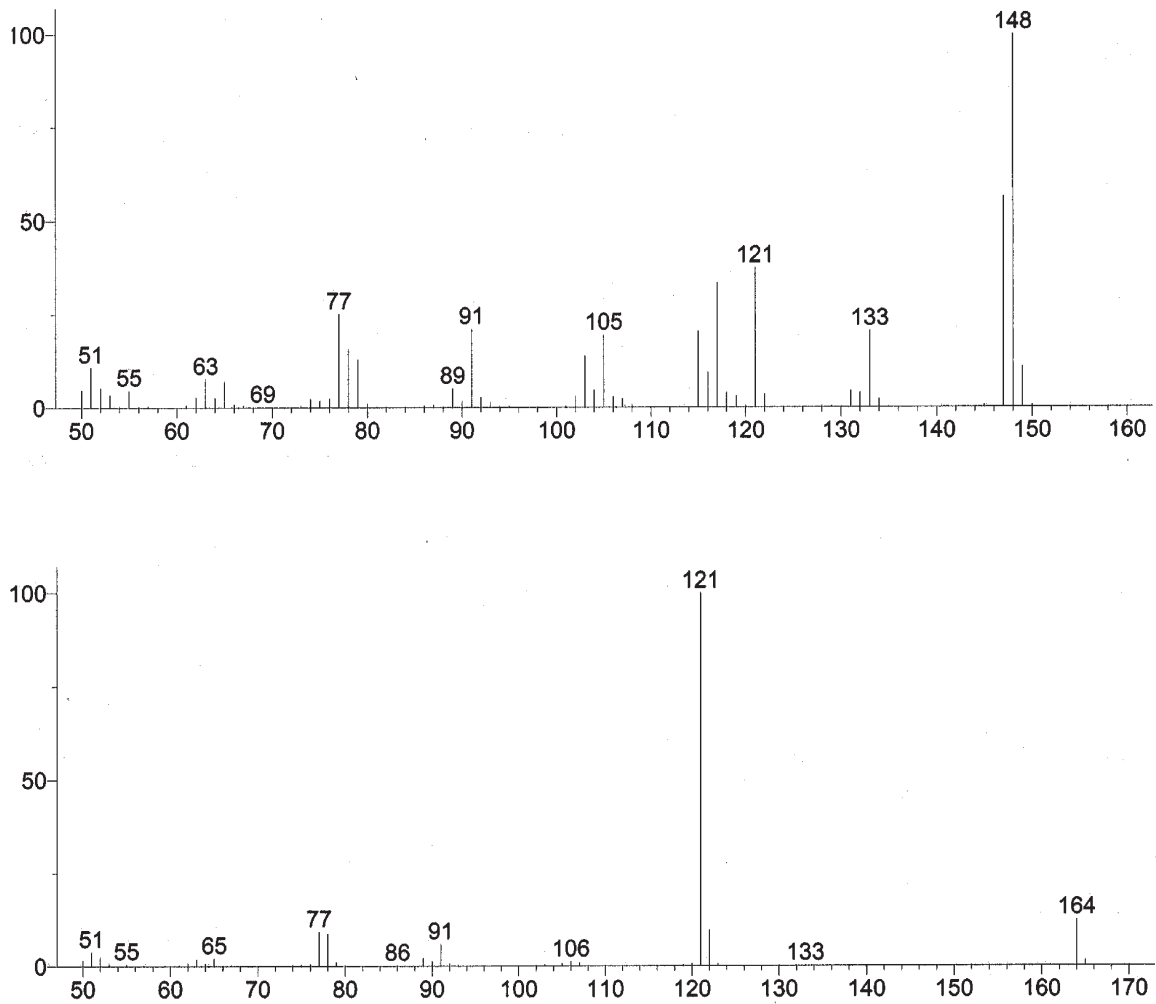

Fig. 4. Electron impact mass spectra of estragole, 3, (top) and anisacetone, 4, (bottom). 
up to $10 \%$ monoterepene hydrocarbons). The differences were that Macedonian sweet fennel was poor in monoterpene hydrocarbons (limonene 7, $\alpha$-pinene $\mathbf{9}$, camphene 12, $\alpha$-phelandrene, 15) compared to the Turkish sweet fennel from Akgül and Bayrak studies (1988), but was rich in anisaldehyde. The relatively high content of trans-anethole $(70 \%)$ and low content of the bitter-tasting fenchone $(0.5 \%)$ of essential oil from this study, ensures sweet fennel oil of high quality.

The identity of the main component, trans-anethole, was confirmed indirectly by potassium permanganate oxidation of the essential oil (Scheme 1). The oxidation product of this reaction, $p$-methoxybenzoic acid, 16, was isolated and characterized by its melting point, mixed melting point with authentic sample and comparison of IR spectra. With this "classical" degradation experiment the position of the double bond and the substitution of the benzene ring in the main component, anethole, was additionally confirmed. It is important to note that under the reaction conditions, the anisaldehyde present will also be oxidized to $p$-methoxybenzoic acid. The yield of $\mathbf{1 6}$ was rather low, but this was not surprising. Alkene oxidative cleavage reactions utilizing potassium permanganate are known to give products in low to moderate yields (McMurry, 2004).

In principle secondary reaction products can be generated if preservation and/or processing of fennel fruit and the essential oil are improperly done. Understanding the mechanisms of these chemical transformations is important in order to maintain the quality and to increase the stability of theses valuable products. Trans-anethole present in the fennel fruit and in the essential oil is susceptible to oxidation, but it is very unlikely that even under improper storage conditions it can be oxidized directly to $\mathbf{1 6}$. This type of alkene oxidative cleavage requires quite powerful oxidizing agents. In the fennel the oxidation of anethole most likely occurs stepwise via several intermediate products (Kitajima et al., 1999). The potential products of autooxidation of trans-anethole (epoxy anethole, anethole glycol and 16) were not detected in freshly obtained essential oils using GC-MS.

\section{Conclusion}

The essential oil of sweet fennel can be easily isolated by distillation and subsequent extraction from the fruits of Foeniculum vulgare Mill. ssp. vulgare var. dulce Batt. and Trab.. Thin layer chromatography provides rapid qualitative analysis of the oil especially for trans-anethole, and anisaldehyde. The complete qualitative and quantitative analysis of the main components was accomplished by GC/MS. The main component, trans-anethole, was isolated from the essential oil using column chromatography. Its identity can be indirectly confirmed by potassium permanganate oxidation of the essential oil. The isolated and characterized 4-methoxybenzoic acid, 16, from this reaction is of significance because it is the final product of the autoox- idation of anethole. The potential products of autooxidation of trans-anethole (epoxy anethole, anethole glycol and 16) were not detected in the freshly obtained essential oils. When it comes to the fennel fruits and the corresponding essential oils, susceptibility of trans-anethole to oxidation has to be taken in consideration and excessive heat (or other) treatment should be avoided. Based on the above-mentioned results (high content of trans-anethole and low content of fenchone) and the absence of intermediate products of autooxidation, it can be concluded that the fennel fruits and the obtained essential oils are of high quality. We plan to investigate in details the mechanism of autooxidation by employing milder oxidizing agents and we are in process of developing alternative methods for detection of the potential autooxidation products.

\section{Acknowledgement}

We would like to thank OPCW and European Union for their generous donation of GC-MS instrument and accompanying accessories.

\section{References}

Adams, R. P., 1995. Identification of Essential Oil Components by Gas Chromatography/Mass Spectroscopy. $1^{\text {st }}$ ed., Allured Publishing Co., Illinois, USA.

Akgul, A., Bayrak, A., 1988. Comparative volatile oil composition of various parts from Turkish bitter fennel (Foeniculum vulgare var. vulgare). Food Chem. 30(4), 319-323.

Azeez, A., 2008. Fennel, in: Parthasarathy, V.A., Chempakam, B., Zachariah, T.J. (Eds.) Chemistry of Spices, CAB International, New Delhi, pp. 227-241.

Dervendji, V., 1986. Prirodni Lekoviti i Aromatični Surovini, $1^{\text {st }}$ ed., Naša Kniga, Skopje, pp.189-191.

European Pharmacopoea (VII) $7^{\text {th }}$ edition, Council of Europe, Strasbourg, 2011.

Garin, D.L., 1980. Steam distillation of essential oils-Anethole from anise followed by permanganate oxidation to anisic acid. J. Chem. Ed. 57, 138-139.

Guenther, E., 1952. The Essential Oils, $6^{\text {th }}$ vol., Van Nostrand, New York, pp. 634-645.

Karlsen, J., Baerheim, S.A., Chingova, B., Zolatovich, G., 1969. Studies on the fruits of Foeniculum species and their essential oil. Planta Med. 1793, 281-293.

Kitajima, J., Ishikawa, T., Tanaka, Y., Ida, Y., 1999. Constituents of fennel. X. New chromanone and phenylethanoid glycosides, and threo-epxyanethole. Chem. Pharm. Bull. 47, 1445-1447.

Kulevanova, S., 2004. Farmakognozija, Kultura, Skopje.

Krishna, A.D., 2004. The genus Foeniculum, in: Jodral, M.M., (Ed.), Illicium, Pimpinella and Foeniculum. CRC Press, Boca Raton, pp. 218-226.

Lawless, J., 1995. The Illustrated Encyclopedia of Essential Oils: The Complete Guide to the Use of Oils in Aromatherapy and Herbalism, $2^{\text {nd }}$ ed., Element Books Ltd., London, pp. 13.

Lawrence, B.M., 1980. New trends in essential oils. Perfumes Flav. 5, 6-16.

Lide, D.R., 2003. CRC Handbook of Chemistry and Physics, CRC Press, Boca Raton, Florida. 
Maarse, H., Visscher, C.A., 1989. Volatile Compounds in FoodQualitative and Quantitative Data, TNO-CIVO Food Analysis Institute, Zeist, The Nederlands.

Maarse, H., 1991. Volatile Compounds in Foods and Beverages, CRC Press Inc., Boca Raton, pp 465-466.

McMurry, J., 2004. Organic chemistry, $6^{\text {th }}$ ed., Brooks/Cole, Pacific Grove, CA, pp. 225-226.

O’Neil, M. J. C. A. M.; Co, Eds. 2001. The Merck Index : An
Encyclopedia of Chemicals, Drugs, and Biologicals; $13^{\text {th }}$ ed. Merck: Whitehouse Station, NJ, USA.

Still, W.C., M. Kahn, M. Mitra, A., 1978. Rapid chromatographic technique for preparative separation with moderate resolution. J. Org. Chem. 43, 2923-2925.

Wiley Registry, $8^{\text {th }}$ edition/NIST 2005, Mass Spectral Library, (W8/N05).

\title{
Резиме
}

\section{TLC и GC-MS анализи на етерично масло изолирано од македонски Foeniculi fructus}

\author{
Менче Најдоска $^{1}$, Јане Богданов ${ }^{1 *}$, Зоран Здравковски ${ }^{1}$ \\ 'Институт за Хемија, Природно-математички факултет, Универзитет „Св. Кирил и Методиј”, Архимедова 5 , \\ МК-1001, Скопје, Република Македонија
}

Клучни зборови: Foeniculum vulgare Mill. ssp.vulgare var. dulce, етерично масло од сладок анасон, хемиски состав, GC-MS, transанетол.

Изолацијата на етерично масло од Foeniculi fructus, зрелиот плод од Foeniculum vulgare Mill. ssp. vulgare var. dulce (aнг. sweet fennel, македонски анасон) беше извршена и главните компоненти беа идентификувани и квантифицирани користејќ тенкослојна хроматографија (TLC) и гасен хроматограф спрегнат со масен спектрометар (GS-MS). Aetherloeum Foeniculi имаше бледо жолта боја и карактеристичен пријатен мирис и беше изолиран во принос од $3,2 \%$ (од масата на плодовите). Главните компоненти на етеричното масло се: trans-анетол 1, (70\%), p-анисалдехид, 2, (19\%) естрагол, 3, (6\%) и анисацетон, 4, (2\%). Идентитетот на компонентите беше одреден преку споредба на добиените масени спектри со спектри од компјутерска библиотека. Идентитетот на главната компонента, trans-анетол, беше потврден директно со изолација со хроматографија во колона и индиректно преку оксидација на етеричното масло со калиум перманганат. Оксидациониот продукт од оваа реакција, $p$-метоксибензоева киселина, 16, беше изолиран и карактеризиран. Потенцијалните продуктите на автооксидацијата на trans-анетол (епоксианетол, анетол гликол и 16) не беа детектирани во свежо добиените етерични масла. 